\section{Commentary: Can the Trifecta GT really go the distance?}

\author{
Ming Hao Guo, MD, and \\ Munir Boodhwani, MD, MSc
}

Tchouta and colleagues ${ }^{1}$ describe 3 cases of early failure of the Trifecta Glide Technology (GT) valve (Abbott Vascular, Santa Clara, Calif). ${ }^{1}$ The valve failures occurred between 1.9 and 3.2 years after implantation, with detachment of a noncoronary cusp at the stent post causing severe aortic insufficiency and heart failure in all 3 cases. One patient also had circumferential pannus formation. The authors noted that the valves were implanted by 3 different surgeons, the valves were not oversized, there was no evidence of infective endocarditis, and the leaflets in all 3 valves were pliable, with no evidence of calcification. At the authors' institution, the cumulative incidence of Trifecta GT valve failure for those valves implanted between 2016 and 2017 was $3.3 \%$ at 3.5 years of follow-up after accounting for competing events of endocarditis and non-cardiac-related death.

The St Jude Medical (St Paul, Minn) Trifecta GT valve received US Food and Drug Administration approval in 2011 and has been shown to provide improved effective orifice area and gradient compared with other stented bioprosthetic aortic valves, leading to a lower incidence of patient-prosthetic mismatch. ${ }^{2}$ In addition, one study showed increased left ventricular mass regression with the Trifecta GT valve compared with the Magna Ease valve (Edwards LifeSciences, Irvine, Calif). ${ }^{3}$ Initial studies for the Trifecta GT valve also demonstrated excellent shortterm durability ${ }^{4}$; however, there have been discrepancies in reporting of mid-term outcomes, with an incidence in structural valve degeneration (SVD) ranging from $1.3 \%$

\footnotetext{
From the Division of Cardiac Surgery, University of Ottawa Heart Institute, Ottawa, Ontario, Canada.

Disclosures: The authors reported no conflicts of interest.

The Journal policy requires editors and reviewers to disclose conflicts of interest and to decline handling or reviewing manuscripts for which they may have a conflict of interest. The editors and reviewers of this article have no conflicts of interest.

Received for publication Aug 27, 2020; revisions received Aug 27, 2020; accepted for publication Aug 28, 2020; available ahead of print Nov 30, 2020.

Address for reprints: Munir Boodhwani, MD, MSc, University of Ottawa Heart Institute, 340-40 Ruskin St, Ottawa, Ontario, Canada K1Y 4W7 (E-mail: mboodhwani@ottawaheart.ca).

JTCVS Techniques 2021;5:23-4

2666-2507

Copyright (C) 2020 The Authors. Published by Elsevier Inc. on behalf of The American Association for Thoracic Surgery. This is an open access article under the CC BY-NCND license (http://creativecommons.org/licenses/by-nc-nd/4.0/).

https://doi.org/10.1016/j.xjtc.2020.08.082
}

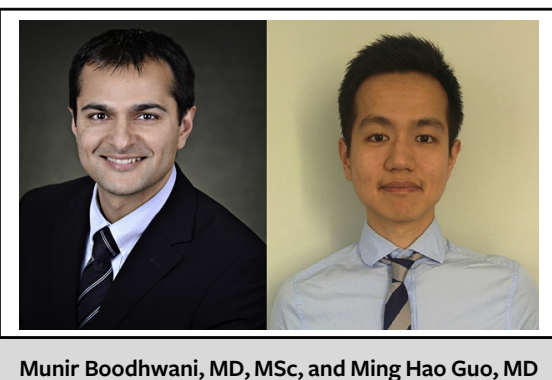

\section{CENTRAL MESSAGE \\ More data will be required to determine the pathophysiology, incidence, and progression of structural valve deterioration and to determine whether the Trifecta GT valve can go the distance.}

at 5 years to $13.1 \%$ at 6 years. ${ }^{5-7}$ Twenty-one cases of Trifecta GT valve SVD have been published in the literature, with both stenotic and regurgitant pathology. ${ }^{7}$ SVD typically presented with calcification of the cusps, whereas regurgitant valves mostly exhibited a yellow fibrofatty deposit attached circumferentially to either the aortic or subannular portion of the valve, causing cusp retraction, or partial cusp tear along the stent post, most commonly the noncoronary cusp.

The Trifecta GT was introduced in 2016. It included new features to protect the leaflets from knot tying and increased leaflet tissue tensile strength to improve fatigue resistance, a streamlined holder with legs positioned in front of the leaflets, a softer sewing cuff, and new treatment of the leaflet with a collagen fiber alignment technology. ${ }^{8,9}$ However, in the 3 patients reported by the authors, detachment of the noncoronary cusp, which is one of the main issues leading to aortic regurgitation in the first generation of Trifecta valves, appears to have persisted.

At this time, the fate of the Trifecta GT valve remains unclear. With only mid-term follow-up of the first-generation valve and early use of the GT valve, as well as varying reporting on outcomes in the literature, use of the valve will be evaluated by a proper assessment of its hemodynamic benefit versus the risk of SVD in the long term. As the authors pointed out, this is the first published case series of Trifecta GT SVD. The UK Medicines and Healthcare 
Products Regulatory Agency had received 5 adverse incident reports related to the Trifecta GT as of January 2020; however, the number of these incidents that were related to SVD was not reported. ${ }^{8}$ In the earlier series, it had been hypothesized that cusp tear caused by mechanical stress at the sutures near the stent post, as well as a possible relationship between implantation technique and oversizing, core-knot placement, and bending of strut posts during hand-tying, all of which may lead to damage of the leaflet or the titanium stent, might have account for the discrepant outcomes. ${ }^{10}$ It is possible that mechanical stress at the junction between the right and noncoronary cusps remains a problem; however, surgeon-specific technical factors also may have a role in early valve failure. As a benchmark for bioprosthetic aortic valves in a large series, the Magna Ease aortic valve had an actuarial explant for SVD of $1.9 \%$ at 10 years and $15 \%$ at 20 years. ${ }^{11}$ Ultimately, more data are needed to determine the pathophysiology, incidence, and progression of SVD and to evaluate whether the Trifecta GT valve can go the distance.

\section{References}

1. Tchouta L, Liesman D, Kim K, Fukuhara S. Early failure of the Trifecta GT bioprostheses. J Thorac Cardiovasc Surg Tech. 2020;4:106-8.
2. Goldman S, Cheung A, Bavaria JE, Petracek MR, Groh MA, Schaff HV. Midterm, multicenter clinical and hemodynamic results for the Trifecta aortic pericardial valve. J Thorac Cardiovasc Surg. 2017; 153:561-9.e2.

3. Rubens FD, Gee YY, Ngu JM, Chen L, Burwash IG. Effect of aortic pericardial valve choice on outcomes and left ventricular mass regression in patients with left ventricular hypertrophy. J Thorac Cardiovasc Surg. 2016;152:1291-8.e2.

4. Bavaria JE, Desai ND, Cheung A, Petracek MR, Groh MA, Borger MA, et al. The St Jude Medical Trifecta aortic pericardial valve: results from a global, multicenter, prospective clinical study. J Thorac Cardiovasc Surg. 2014;147:590-7.

5. Fukuhara S, Shiomi S, Yang B, Kim K, Bolling SF, Haft J, et al. Early structural valve degeneration of Trifecta bioprosthesis. Ann Thorac Surg. 2020;109:720-7.

6. Kalra A, Rehman H, Ramchandani M, Barker CM, Lawrie GM, Reul RM, et al. Early Trifecta valve failure: report of a cluster of cases from a tertiary care referral center. J Thorac Cardiovasc Surg. 2017;154:1235-40.

7. Kaneyuki D, Nakajima H, Asakura T, Yoshitake A, Tokunaga C, Tochii M, et al. Early first-generation Trifecta valve failure: a case series and a review of the literature. Ann Thorac Surg. 2020;109:86-92.

8. GOV.UK, Medicines and Healthcare products Regulatory Agency (MHRA). Abbott Trifecta/Trifecta GT bioprosthetic aortic heart valves: cases of structural valve deterioration (SVD) (MDA/2020/019). Available at: https://www.gov.uk/ drug-device-alerts/abbott-trifecta-trifecta-gt-bioprosthetic-aortic-heart-valvescases-of-structural-valve-deterioration-svd-mda-2020-019. Accessed August $23,2020$.

9. Hamamoto M, Kobayashi T, Ozawa M, Yoshimura K. Pure cusp tear of Trifecta bioprosthesis 2 years after aortic valve replacement. Ann Thorac Cardiovasc Surg. 2017;23:157-60.

10. Kilic A. Structural valve deterioration with the Trifecta: is it the valve or is it implant technique? Ann Thorac Surg. 2020;110:888-9.

11. Johnston DR, Soltesz EG, Vakil N, Rajeswaran J, Roselli EE, Sabik JF III, et al. Long-term durability of bioprosthetic aortic valves: implications from 12,569 implants. Ann Thorac Surg. 2015;99:1239-47. 